\title{
HUBUNGAN ANEMIA DALAM KEHAMILAN DENGAN PANJANG BADAN BAYI BARU LAHIR DI RUMAH SAKIT BENYAMIN GULUH KABUPATEN KOLAKA TAHUN 2018
}

\author{
Kartini \\ Jurusan Kebidanan Poltekkes Kemenkes Kendari ${ }^{1}$
}

\begin{abstract}
ABSTRAK
Latar belakang: Pada ibu hamil dengan anemia terjadi gangguan penyaluran oksigen dan zat makanan dari ibu ke plasenta dan janin, yang mempengaruhi fungsi plasenta. Fungsi plasenta yang menurun dapat mengakibatkan gangguan tumbuh kembang janin.

Tujuan penelitian: Untuk mengetahui hubungan anemia dalam kehamilan dengan panjang badan bayi baru lahir di Rumah Sakit Benyamin Guluh Kabupaten Kolaka Tahun 2018.

Metode Penelitian: Desain penelitian yang digunakan ialah case control. Sampel penelitian adalah bayi yang lahir pada tahun 2018 yang berjumlah 84 bayi. Instrumen pengumpulan data berupa lembar pengisian. Analisis data mengunakan uji chi square dan $O R$

Hasil Penelitian: Panjang badan bayi yang $<48 \mathrm{~cm}$ sebanyak 42 orang $(11,73 \%)$. Ada hubungan anemia dalam kehamilan dengan panjang badan bayi di Rumah Sakit Benyamin Guluh Kabupaten Kolaka $\left(X^{2}=12,5 ; p=0,00\right)$. Ibu yang mengalami anemia berisiko 5,95 kali bayinya memiliki panjang badan lahir $<48 \mathrm{~cm}(\mathrm{OR}=5,95 ; 95 \% \mathrm{CI}=2,27-15,6)$.
\end{abstract}

Kata kunci : panjang badan lahir, anemia dalam kehamilan

\section{LATAR BELAKANG}

Kesehatan ibu dan bayi merupakan salah satu masalah kesehatan yang hingga saat ini masih mendapat perhatian pemerintah. Salah satu masalah yang berhubungan dengan ibu dan bayi adalah bayi dan balita yang mengalami gizi buruk dan kurang dan stunting dan berat badan lahir rendah (BBLR). Jumlah kasus stunting di dunia tahun 2017 tertinggi di India sebesar 48,2\%, diikuti Pakistan sebesar 10,0\%, Nigeria sebesar 10,0\% dan Indonesia sebesar 8,8\%. ${ }^{1}$ Jumlah kejadian stunting di Indonesia pada tahun 2018 sebanyak 30,8\% dan di Sulawesi Tenggara sebesar $30,4 \% .^{2}$ Prevalensi BBLR didunia diperkirakan sebesar $15 \%$ dimana $38 \%$ terjadi terutama di negara-negara berkembang. Persentase
BBLR dan sangat kurus di Indonesia sebesar 17,7\% (Kemenkes RI, 2018) dan di Sulawesi Tenggara sebesar $2,29 \%$. $^{3}$

Stunting merupakan salah satu indikator gizi kronis yang dapat memberikan gambaran gangguan kehidupan sosial ekonomi secara keseluruhan di masa lampau yang muncul pada dua sampai tiga tahun awal kehidupan dan ini merupakan refleksi dari akibat atau pengaruh karena kurangnya asupan energi, zat gizi, BBLR dan penyakit infeksi sedangkan BBLR merupakan salah satu penyebab utama kematian, morbiditas dan kecacatan pada neonatus dan bayi serta memiliki dampak jangka panjang pada hasil kesehatan dalam kehidupan dewasa, sehingga merupakan masalah multifaset pada kesehatan masyarakat. $^{2}$ 
Stunting mengindikasi masalah kesehatan masyarakat karena berhubungan dengan meningkatnya risiko morbiditas dan mortalitas, penurunan perkembangan fungsi motorik, mental serta mengurangi kapasitas fisik. Stunting disebabkan oleh akumulasi episode stress yang berlangsung lama, yang kemudian tidak terimbangi oleh catch up growth (kejar tumbuh). Hal ini mengakibatkan menurunnya pertumbuhan apabila dibandingkan dengan anak-anak yang tumbuh dalam lingkungan yang mendukung. ${ }^{4}$

Stunting juga akan berdampak pada

Indeks Pembangunan Manusia (IPM) Indonesia sekarang berada pada peringkat 113 dari 188 negara di seluruh dunia. Rendahnya IPM ini dipengaruhi oleh status gizi dan kesehatan penduduk Indonesia ditunjukkan dengan tingkat kemiskinan dan kelaparan sekitar 140 juta orang yang hidup dengan biaya kurang dari Rp 20.000/hari dan 19,4 juta orang menderita gizi buruk. Tingginya angka kematian bayi, balita dan ibu menunjukkan hasil yang belum maksimal pada upaya perbaikan atau pemerataan pelayanan kesehatan di Indonesia. $^{2}$

Demikian pula bayi (BBLR) berisiko kematian 35 kali lebih tinggi dibandingkan dengan bayi dengan berat lahir normal. Di negara berkembang diperkirakan setiap 10 detik terjadi satu kematian bayi akibat penyakit atau infeksi yang berhubungan dengan bayi berat lahir rendah. Bayi berat lahir rendah (BBLR) dapat mengakibatkan terjadinya insiden sepsis umbilikalis, gangguan pada mata (ophtalmology), gangguan pendengaran, diare, ikterus neonatorum, infeksi traktus respiratorius, dan yang paling sering ditemukan berupa asfiksia neonatorum. Akibat jangka panjang berat badan lahir rendah (BBLR) antara lain terhadap tumbuh kembang anak, risiko penyakit jantung di masa yang akan datang dan penurunan kecerdasan. Berat Badan lahir rendah (BBLR) merupakan faktor penting dalam morbiditas dan mortalitas perinatal di negara berkembang. ${ }^{5}$

Salah satu faktor yang menyebabkan stunting dan BBLR adalah ibu hamil yang mengalami anemia. Anemia pada ibu hamil meningkatkan risiko mendapatkan Bayi Berat Lahir Rendah (BBLR), stunting, risiko perdarahan sebelum dan saat persalinan, bahkan dapat menyebabkan kematian ibu dan bayinya jika ibu hamil tersebut menderita anemia berat. Hal ini tentunya dapat memberikan sumbangan besar terhadap angka kematian ibu bersalin, maupun angka kematian bayi. ${ }^{6}$ Anemia pada ibu hamil juga terkait dengan mortalitas dan morbiditas pada ibu dan bayi, termasuk risiko keguguran, lahir mati, prematuritas dan berat bayi lahir rendah. ${ }^{1}$

Pada ibu hamil dengan anemia terjadi gangguan penyaluran oksigen dan zat makanan dari ibu ke plasenta dan janin, yang mempengaruhi fungsi plasenta. Fungsi plasenta yang menurun dapat mengakibatkan gangguan tumbuh kembang janin. Anemia pada ibu hamil dapat mengakibatkan 
gangguan tumbuh kembang janin, abortus, partus lama, sepsis puerperalis, kematian ibu dan janin, meningkatkan risiko berat badan lahir rendah, asfiksia neonatorum, prematuritas. ${ }^{6,7,8}$

Hasil penelitian menyatakan hubungan antara anemia pada ibu hamil dengan berat badan bayi baru lahir di BPS Kertosuko Kecamatan Krucil Kabupaten Probolinggo. ${ }^{9}$ Demikian pula hasil penelitian menyatakan ada hubungan yang signifikan riwayat anemia kehamilan dengan kejadian stunting pada balita di Desa Ketandan Dagangan Madiun. Ibu hamil yang menderita anemia memiliki risiko 4 kali terjadinya anak mengalami stunting dibandingkan dengan ibu yang tidak anemia. ${ }^{10}$

Data awal yang diperoleh di Rumah Sakit Benyamin Guluh Kabupaten Kolaka diperoleh data jumlah bayi baru lahir pada tahun 2016 sebanyak 313 bayi, pada tahun 2017 sebanyak 386 bayi, tahun 2018 sebanyak 358 bayi. Jumlah bayi dengan berat badan <2500 gram tahun 2016 sebanyak 51 bayi (16,29\%), tahun 2017 sebanyak 39 bayi $(10,10 \%)$ dan tahun 2018 sebanyak 76 bayi $(21,23 \%)$. Jumlah bayi dengan panjang badan $<48 \mathrm{~cm}$ tahun 2016 sebanyak 35 bayi (11,18\%), tahun 2017 sebanyak 28 bayi $(7,25 \%)$ dan tahun 2018 sebanyak 42 bayi $(11,73 \%)$. Jumlah ibu bersalin yang mengalami anemia dalam kehamilan tahun 2016 sebanyak $30 \mathrm{ibu}(8,1 \%)$ dari $371 \mathrm{ibu}$ bersalin, tahun 2017 sebanyak $25 \mathrm{ibu}$ (7,29\%) dari 343 ibu bersalin, tahun 2018 sebanyak 35 ibu $(10,12 \%)$ dari $346 \mathrm{ibu}$ bersalin (Rumah Sakit Benyamin Guluh Kabupaten Kolaka, 2018).

Berdasarkan fenomena tersebut maka penulis tertarik melakukan penelitian untuk mengetahui hubungan anemia dalam kehamilan dengan panjang badan bayi baru lahir di Rumah Sakit Benyamin Guluh Kabupaten Kolaka Tahun 2018.

\section{METODE PENELITIAN}

Desain penelitian yang digunakan ialah case control. Sampel penelitian adalah bayi yang lahir pada tahun 2018 yang berjumlah 84 bayi. Instrumen pengumpulan data berupa lembar pengisian. Analisis data mengunakan uji chi square dan $O R$.

\section{HASIL PENELITIAN}

Tabel 1

Distribusi Frekuensi Panjang Badan Bayi Baru Lahir Pada Ibu Hamil Yang Mengalami Anemia di Rumah Sakit Benyamin Guluh Kabupaten Kolaka tahun 2018

\begin{tabular}{ccc}
\hline $\begin{array}{c}\text { Panjang badan } \\
\text { bayi }\end{array}$ & $\mathrm{n}$ & $\%$ \\
\hline$<48 \mathrm{~cm}$ & 42 & 11,73 \\
$\geq 48 \mathrm{~cm}$ & 316 & 88,27 \\
\hline Total & 358 & 100 \\
\hline
\end{tabular}

Sumber: Data Primer 
Tabel 1 menyatakan bahwa jumlah bayi dengan panjang badan $<48 \mathrm{~cm}$ sebanyak 42 bayi $(11,73 \%)$.

Tabel 2

Distribusi Frekuensi Kejadian Anemia Dalam Kehamilan di Rumah Sakit Benyamin Guluh Kabupaten Kolaka tahun 2018

\begin{tabular}{ccc}
\hline $\begin{array}{c}\text { Anemia Dalam } \\
\text { kehamilan }\end{array}$ & $\mathrm{n}$ & $\%$ \\
\hline Ya & 35 & 41,67 \\
Tidak & 49 & 58,33 \\
\hline Total & 84 & 100 \\
\hline
\end{tabular}

Sumber: Data Primer

Tabel 2 menyatakan bahwa jumlah ibu hamil yang mengalami anemia sebanyak 35 orang ibu $(41,67 \%)$.

Tabel 3

Hubungan Anemia Dalam Kehamilan Dengan Panjang Badan Bayi Baru Lahir di Rumah Sakit Benyamin Guluh Kabupaten Kolaka tahun 2018

\begin{tabular}{|c|c|c|c|c|c|c|}
\hline \multirow[t]{2}{*}{ Anemia } & \multicolumn{2}{|c|}{$\begin{array}{c}\text { PB Bayi } \\
<48 \mathrm{~cm}\end{array}$} & \multicolumn{2}{|c|}{$\begin{array}{l}\text { PB Bayi } \\
\geq 48 \mathrm{~cm}\end{array}$} & \multirow{2}{*}{$\begin{array}{l}X^{2} \\
(p)\end{array}$} & \multirow{2}{*}{$\begin{array}{c}\text { OR } \\
(95 \% \\
\text { CI) }\end{array}$} \\
\hline & $\mathrm{n}$ & $\%$ & $\mathrm{n}$ & $\%$ & & \\
\hline Ya & 26 & 61,9 & 9 & 21,4 & $\begin{array}{c}12,5 \\
(0,0 \\
0)\end{array}$ & $\begin{array}{c}5,95 \\
(2,27- \\
15,6)\end{array}$ \\
\hline Tidak & 16 & 38,1 & 33 & 78,6 & & \\
\hline Total & 42 & 100 & 42 & 100 & & \\
\hline
\end{tabular}

Tabel 3 menyatakan bahwa ada hubungan anemia dalam kehamilan dengan panjang badan bayi $\left(X^{2}=12,5 ; p=0,00\right)$. Ibu yang mengalami anemia berisiko 5,95 kali bayinya memiliki panjang badan lahir <48 $\mathrm{cm}(\mathrm{OR}=5,95 ; 95 \% \mathrm{CI}=2,27-15,6)$.

\section{PEMBAHASAN}

Hasil penelitian menyatakan ada hubungan anemia dalam kehamilan dengan panjang badan bayi $\left(X^{2}=12,5 ; p=0,00\right)$. Ibu yang mengalami anemia berisiko 5,95 kali bayinya memiliki panjang badan lahir $<48$ $\mathrm{cm}(\mathrm{OR}=5,95 ; 95 \% \mathrm{CI}=2,27-15,6)$.

Hasil penelitian ini menjukkan bahwa bayi yang ibunya mengalami anemia dalam kehamilannya akan memiliki panjang badan yang lebih pendek dibandingkan bayi yang ibunya tidak mengalami anemia.

Panjang badan (PB) adalah parameter pertumbuhan yang lebih akurat dan digunakan untuk menilai status perbaikan gizi. Panjang badan menggambarkan pertumbuhan linier bayi yang biasanya menunjukkan keadaan gizi yang kurang akibat kekurangan energidan protein yang diderita di waktu lampau. Pengukuran PB bersifat obyektif dan dapat diulang, murah dan mudah dibawa. Ketepatan pembacaan panjang badan dilakukan sampai pada $0,1 \quad \mathrm{~cm}$. PB merupakan indikator yang baik untuk pertumbuhan fisik yang sudahlewat (stunting) dan untuk perbandingan terhadap perubahan relatif, seperti berat badan. ${ }^{11}$

Salah satu faktor yang dapat mempengaruhi berat bayi lahir adalah anemia dalam kehamilan. Menurut Arisman (2014), anemia merupakan keadaan menurunnya kadar hemoglobin, hematokrit, dan jumlah sel darah merah di bawah nilai normal yang dipatok untuk perorangan. Anemia adalah keadaan dimana kadar hemoglobin, hematokrit, dan sel darah merah lebih rendah dari nilai normal, sebagai akibat dari defisiensi salah satu atau beberapa unsur makanan yang esensial yang 
dapat mempengaruhi timbulnya defisiensi tersebut. $^{12}$

Anemia adalah suatu keadaan terjadinya kekurangan baik jumlah maupun ukuran eritrosit atau banyaknya hemoglobin sehingga pertukaran oksigen dan karbondioksida antara darah dan sel jaringan terbatasi. Anemia defisiensi besi adalah suatu keadaan/kondisi sebagai akibat ketidakmampuan sistem eritropoiesis dalam mempertahankan kadar $\mathrm{Hb}$ normal, sebagai akibat kekurangan konsumsi satu atau lebih zat gizi. ${ }^{13}$

Anemia dalam kehamilan sangat mempengaruhi panjang badan bayi yang dilahirkan. Menurut Setianingrum (2015) menyatakan bahwa seorang ibu hamil dikatakan menderita anemia bila kadar hemoglobinnya dibawah 11 gr\%. Hal ini jelas menimbulkan gangguan pertumbuhan hasil konsepsi, sering terjadi immaturitas, prematuritas, cacat bawaan, atau janin lahir dengan berat badan yang rendah, stunting. ${ }^{14}$

Kadar hemoglobin tidak normal pada ibu hamil akan menambah risiko mendapatkan bayi berat lahir rendah (BBLR), dan gangguan perkembangan otak, resiko perdarahan sebelum dan pada saat persalinan, stunting, bahkan dapat menyebabkan kematian ibu dan bayinya, jika ibu hamil tersebut menderita anemia berat. Keadaan ini disebabkan karena kurangnya suplai darah nutrisi akan oksigen pada placenta yang akan berpengaruh pada fungsi plasenta terhadap janin. ${ }^{15}$
Hasil penelitian ini sesuai dengan hasil menyatakan ada hubungan yang signifikan riwayat anemia kehamilan dengan kejadian stunting pada balita di Desa Ketandan Dagangan Madiun. Ibu hamil yang menderita anemia memiliki risiko 4 kali terjadinya anak mengalami stunting dibandingkan dengan ibu yang tidak anemia. ${ }^{10}$

\section{SIMPULAN}

Panjang badan bayi yang $<48 \mathrm{~cm}$ sebanyak 42 orang $(11,73 \%)$. Ada hubungan anemia dalam kehamilan dengan panjang badan bayi di Rumah Sakit Benyamin Guluh Kabupaten Kolaka $\left(X^{2}=12,5 ; p=0,00\right)$. Ibu yang mengalami anemia berisiko 5,95 kali bayinya memiliki panjang badan lahir <48 $\mathrm{cm}(\mathrm{OR}=5,95 ; 95 \% \mathrm{CI}=2,27-15,6)$.

Bagi tenaga medis (bidan atau perawat) khususnya di poli KIA puskesmas agar dapat meningkatkan kualitas informasi mengenai kadar HB normal dalam kehamilan sehingga faktor risiko BBLR dan Stunting anemia dapat diatasi. Untuk meningkatkan pengetahuan ibu hamil tentang anemia perlu dilakukan penyuluhan secara terarah dan terencana kepada ibu hamil oleh bidan mulai tingkat posyandu sampai Puskesmas. Bagi peneliti selanjutnya perlu melakukan penelitian selanjutnya tentang faktor-faktor yang mempengaruhi berat badan dan panjang badan bayi baru lahir. 


\section{DAFTAR PUSTAKA}

1. World Health Organization. (2017) Promoting Proper Feeding For Infants and Young Children. Geneva: WHO.

2. Kemenkes RI (2018) Laporan Nasional Riset Kesehatan Dasar (Riskesdas) tahun 2018. Jakarta: Badan Penelitian Pengembangan Kesehatan Depertemen Kesehatan Republik Indonesia.

3. Dinkes Sultra, (2017) Profil Kesehatan Sulawesi Tenggara Tahun 2017. Kendari: Dinkes Sultra.

4. Kusharisupeni. (2016) Growth Faltering Pada Bayi di Kabupaten Indramayu Jawa Barat. Universitas Indonesia. http://journal.ui.ac.id/upload/artikel. Diakses 10 Desember 2018.

5. Manuaba, I.B.G. (2016) Ilmu Kebidanan, Penyakit Kandungan dan Keluarga Berencana untuk Pendidikan Bidan. Jakarta: EGC.

6. Kusuma, (2015) Perawatan Ibu Hamil. Yogyakarta: Fitramaya.

7. Karasahin E, Ceyhan ST, Goktolga U, Keskin U, Baser I. (2015) Maternal Anemia and Perinatal Outcome. Perinatal Journal Vol 15.

8. Hailu, M., Gebremariam, A., \& Alemseged, F. (2010). Knowledge about obstetric danger sign among pregnant women in aleta wondo district, Sidama Zone, Southern Ethiophia. Ethiophia Journal Health Science, 20(1), 25-32.

9. Aprilisa, Yulifa, Susmini (2017) Hubungan Antara Anemia Pada Ibu Hamil Dengan Berat Badan Bayi Baru Lahir di BPS Kertosuko Kecamatan Krucil Kabupaten Probolinggo. Skripsi.

10. Widyaningrum, D.A, Romadhoni, D.A. (2018) Hubungan Riwayat Anemia Kehamilan Dengan Kejadian Stunting Pada Balita di Desa Ketandan Dagangan Madiun. Jurnal Kebidanan Solo.
11. Neil,W. R. (2015) Panduan Lengkap Perawatan Kehamilan. Jakarta: Dian Rakyat.

12. Setianingrum, S.I.W. (2015) Hubungan antara kenaikan berat badan, lingkar lengan atas dan kadar haemoglobin ibu hamil trimester III dengan berat bayi lahir di Puskesmas Ampel I Boyolali. Skripsi. Universitas Negeri Semarang.

13. Sulistyawati, (2017) Asuhan Kebidanan Pada Ibu Hamil. Jakarta: EGC.

14. Saifuddin, A.B. (2012) Buku Panduan Praktis Pelayanan Kesehatan Maternal dan Neonatal. Jakarta: Yayasan Bina Pustaka Sarwono Prawiroharjdo

15. Kementerian Kesehatan RI. (2017) Profil Kesehatan Indonesia Tahun 2017. Jakarta: Kemeneks RI. 